\title{
Ewing's Sarcoma: imaging findings of a patient with primary tumor in the femur and mandibular metastasis
}

Sarcoma de Ewing: achados imaginológicos de um paciente com tumor primário no femur e metástase mandibular

Fabrício Rezende AMARAL ${ }^{1}$

(iD) ORCID iD 0000-0001-9632-5077

Amaro llídio Vespasiano SILVA'

(iD) ORCID iD 0000-0002-4829-6782

Marcelo Matos GARCIA 1

(iD) ORCID iD 0000-0003-0536-6143

Claudia Scigliano VALÉRIO'

(iD) ORCID iD 0000-0002-7850-4845

Cláudia Assunção Alves CARDOSO ${ }^{1}$

(iD) ORCID iD 0000-0003-1718-2237

Flávio Ricardo MANZI ${ }^{1}$

(iD) ORCID iD 0000-0001-9467-5137

\section{ABSTRACT}

Ewing's Sarcoma, a common primary bone malignancy that usually occurs in childhood and young adults, has a predilection for males and occurs mostly in the diaphysis of long bones and pelvis. This tumor rarely affects the head and neck. Histologically, this neoplasm is a small round cell tumor and there is evidence of a neuroectodermal origin. Radiographic findings of ES show an osteolytic lesion, that is not a pathognomonic feature for this neoplasm. The association of conventional imaging methods such radiography, Computed Tomograph (CT), magnetic resonance imaging (MRI), combined with scintigraphy or Positron Emission Tomography/ Computed tomography PET (CT), is essential for a correct diagnosis and treatment. Therefore, the aim of this report was to present image findings of a patient who presented with ES in the femur, and a metastasis in the mandible after eighteen months, and discuss the importance of imaging methods for a correct diagnosis, treatment and consequently, prognosis.

Indexing terms: Ewing's sarcoma. Mandible. Magnetic resonance imaging. Computed tomograph. Positron emission tomography.

\section{RESUMO}

O Sarcoma de Ewing é uma malignidade óssea primária comum que usualmente afeta crianças e adultos jovens. O Sarcoma de Ewing tem predileção por homens e acomete na maioria das vezes a diáfise dos ossos longos e a pelve. Raramente esse tumor afeta a região de cabeça e pescoço. Histologicamente essa neoplasia é composta por células redondas e há evidências de uma origem neuroectodérmica. Os Achados radiográficos do SE mostram uma lesão osteolítica que não é característica patognomonica. A associação dos métodos convencionais, como radiografia, tomografia computadorizada, ressonância magnética combinadas com cintilografia ou tomografia por emissão de positron são essenciais para o correto diagnóstico e tratamento. Desta forma,o objetivo desse trabalho é apresentar os achados imaginológicos de um paciente que apresentou Sarcoma de Ewing primário no femur e uma metástase mandibular após dezoito meses e discutir a importância dos métodos de imagem adequados para um correto diagnóstico, tratamento e consequentemente o prognóstico.

Termos de indexação: Sarcoma de Ewing. Mandíbula. Imagem por ressonância magnética. Tomografia computadorizada por raios X. Tomografia por emissão de positron.

\section{INTRODUCTION}

Ewing's Sarcoma (ES) was first described by James Ewing in 1921 [1] and it is a common primary bone malignancy that usually occurs in childhood and young adults. It is the second most common bone malignancy in children, after osteosarcoma [2]. Histologically, ES is a small round cell tumor and its pathogenesis remains uncertain, although there is evidence of a neuroectodermal origin [3]. Most patients with ES have a common chromosomal translocation involving $\mathrm{t}(11 ; 12)(\mathrm{q} 24 ; \mathrm{q} 12)[4]$. In the WHO classification, the term ES comprises five entities: classical ES, Askin tumor (small round cell tumor of the chest wall), primitive neuroectodermal tumor (PNET), atypical ES and

\footnotetext{
${ }^{1}$ Pontifícia Universidade Católica de Minas Gerais, Faculdade de Odontologia, Departamento de Radiologia Oral. Rua Dom José Gaspar, 500, Prédio 45, 30535-901, Coração Eucarístico, Belo Horizonte, MG, Brasil. Correspondência para / Correspondence to: FR AMARAL. Email: <framaral2@ gmail.com>
}

$\mathbf{v} \mathbf{v}$

Como citar este artigo / How to cite this article

Amaral FR, Silva ALV, Garcia MM, Valério CS, Cardoso CAA, Manzi FR. Ewing's Sarcoma: imaging findings of a patient with primary tumor in the femur and mandibular metastasis. RGO, Rev Gaúch Odontol. 2018;66(3):285-289. http://dx.doi.org/10.1590/1981-8637201800030000153497 
extra skeletal ES [5]. ES has a predilection for the male gender and occurs mostly in the diaphysis of long bones and pelvis [6]. This tumor rarely affects the head and neck, with an incidence of $1 \%$ to $9 \%$ of all cases. Less than $3 \%$ originate in the jaws and the posterior mandible is the most common site [7]. The most common symptoms of ES are localized pain that appears before imaging alterations and intensifies over time, followed by swelling. Other symptoms include fever, anemia and leukocytosis [8]. Radiographic findings of ES show an osteolytic lesion that is not a pathognomonic feature [9]. In the mandible these lesions are characterized by a periosteal reaction named "sun ray" spicules and in long bones the image finding is characterized by an appearance of "onion skinning" $[10,11]$. Other diseases such as osteosarcoma, lymphosarcoma, osteomyelitis and metastatic carcinoma may also exhibit this pattern [12]. Due to the low incidence of ES in the jaws, it is rarely considered in the differential diagnosis of radiolucent lesions [13]. Treatment of ES usually consists of combined surgical resection, radiotherapy and chemotherapy [14]. Metastasis occurs in up to $85 \%$ of patients within 2 years of diagnosis [15]. The presence of metastasis at the time of diagnosis is very important for prognosis [16]. We present the imaging findings of a rare case of a patient who presented a primary ES diagnosed in the femur, with occurring metastasis in the mandible.

\section{CASE REPORT}

Figure 1, the patient, a 6-year-old girl complaining of pain and swelling in her left leg was diagnosed with ES after the conventional radiograph was taken, and magnetic resonance imaging (MRI) and incisional biopsy were performed at an oncology center.

Shows the conventional radiograph with the presence of a radiolucent area with periosteal reaction in the distal region of the diaphysis on the left femur. The hypointense area on the T1-weighted magnetic resonance imaging of the femur with fat suppression after contrast, revealed an expansive mass, involving the cortical and the presence of extensive periosteal reaction (Figure 2).

The treatment was radical surgery with amputation of the leg and adjuvant chemotherapy. The patient was rehabilitated with a metal prosthesis later. After eighteen months, the patient had pain and swelling in the left side of the mandible. A computed tomography (CT) exam was performed, and in the sagittal and axial sections it revealed a destructive lesion with bone expansion and periosteal reaction in the ascending branch of the mandible on the left. (Figure 3A and 3B).

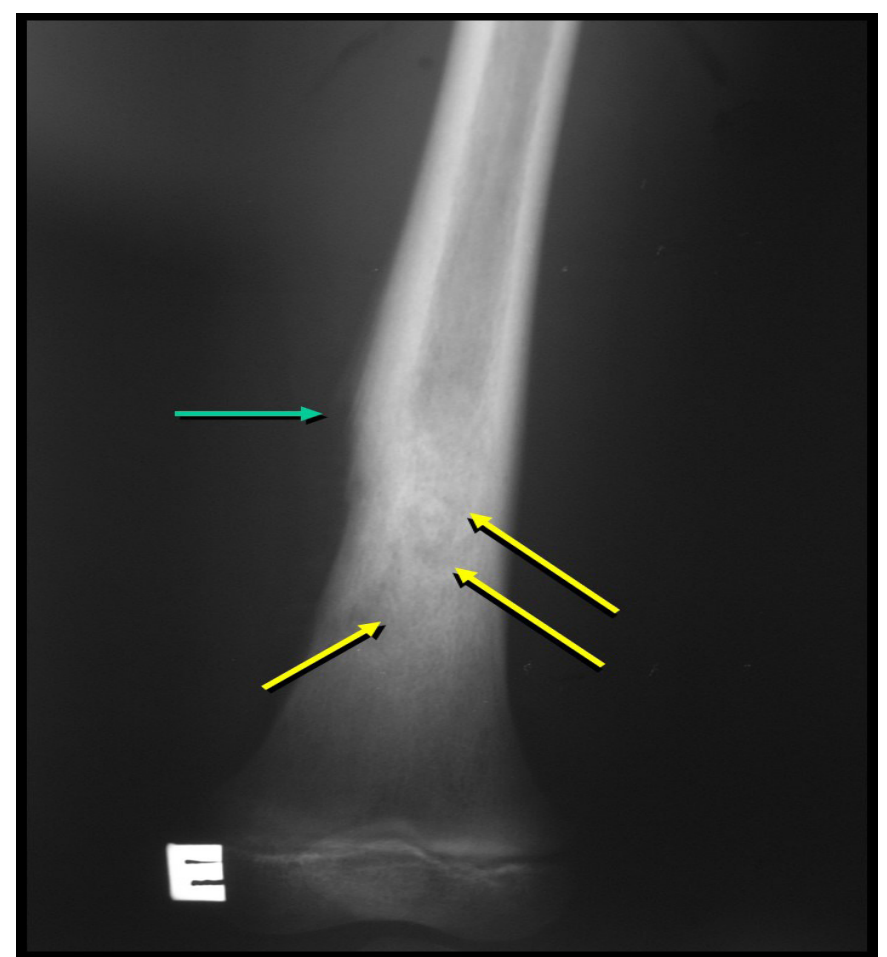

Figure 1. Conventional radiograph. Presence of a radiolucent area (yellow arrows) and periosteal reaction in the distal region of the diaphysis on the left femur (green arrow).

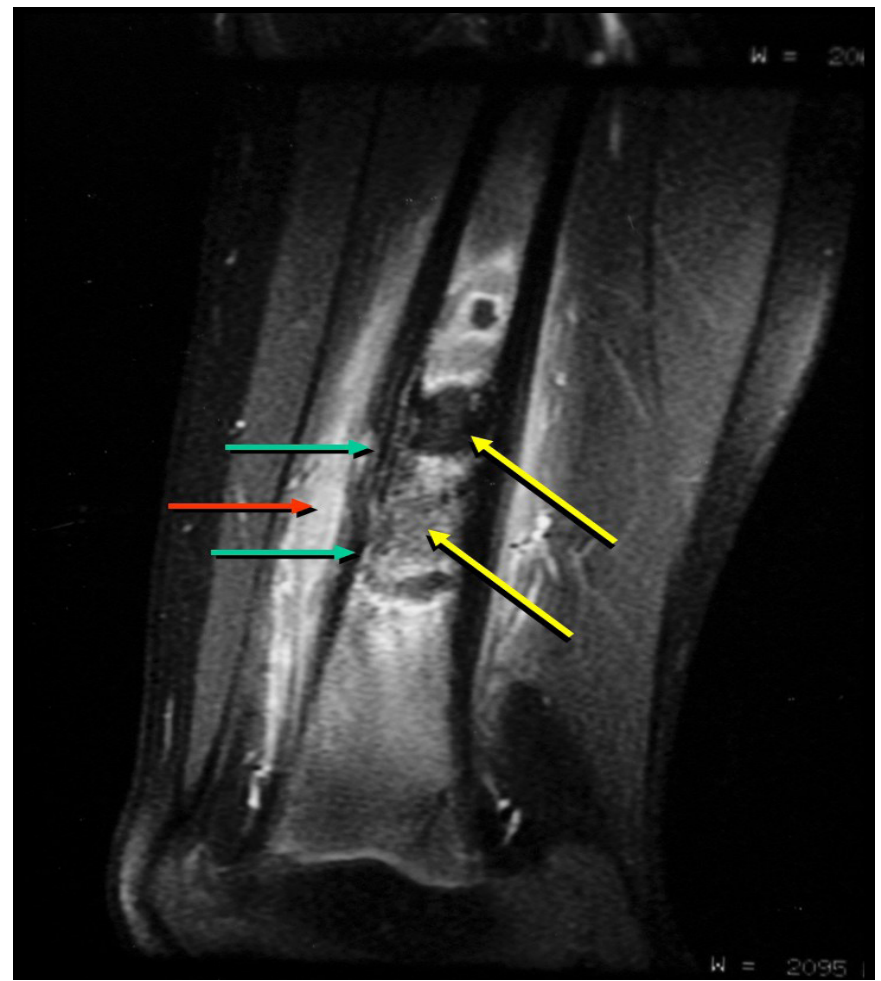

Figure 2. Magnetic Resonance Imaging: hypointense area on the T1-weighted image of the femur with fat suppression after contrast, revealed expansive mass (yellow arrows), involving cortical (green arrows) and the presence of extensive periosteal reaction (red arrow). 

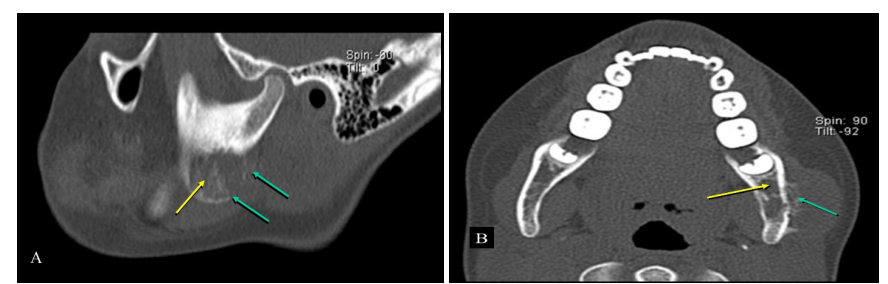

Figure 3. Computed Tomograph: Sagittal slice (3A) and Axial slice (3B). Destructive lesion (yellow arrows) with bone expansion and periosteal reaction (green arrows) in the ascending branch of the mandible on the left.

The coronal slice revealed the presence of destruction of the buccal and lingual cortical (Figure 4A). The soft tissue window showed the presence of an extraosseous tumor mass (Figure 4B).

An incisional biopsy was performed and confirmed an ES. Patient underwent chemotherapy and after one year of treatment, a coronal slice of the computed tomography exam showed reduction of the lesion (Figure 5).
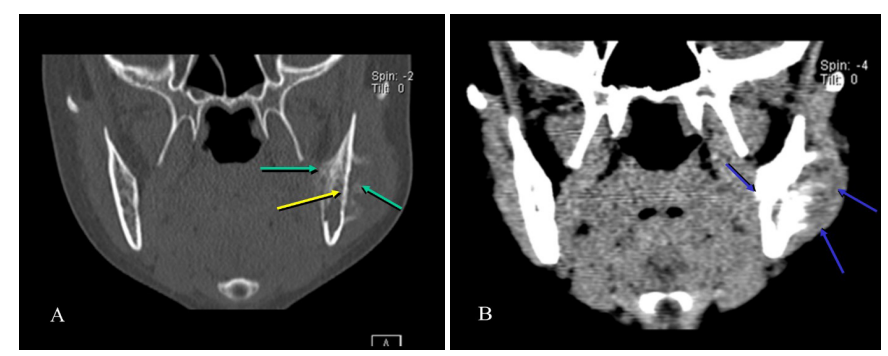

Figure 4. Computed Tomograph: Coronal slice. Destruction of the buccal and lingual cortical (4A) and extra-osseous tumor mass in the soft tissue window (blue arrows) (4B).

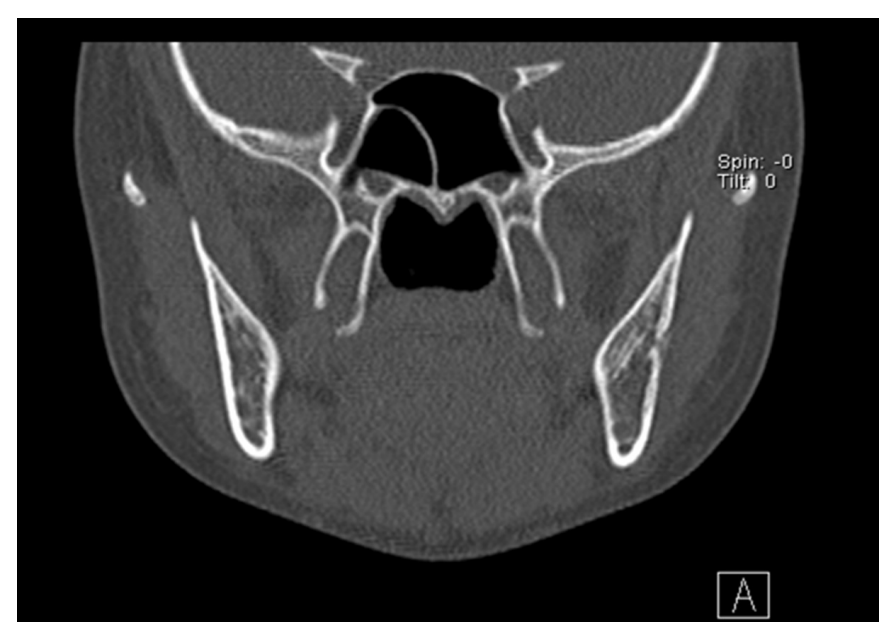

Figure 5. Computed Tomograph: Coronal slice. Destruction of the buccal and lingual cortical (4A) and extra-osseous tumor mass in the soft tissue window (blue arrows) (4B).

\section{DISCUSSION}

ES is the second most frequent primary bone tumor in children and occurs mostly in the long bones [2]. It is very rare in the jaws and may result from metastasis from another skeletal site [17]. The present case demonstrated a rare case of a patient with a primary tumor detected in the femur and a metastasis in mandible, diagnosed within a period of eighteen months. Up to $85 \%$ of patients have metastases within 2 years after diagnosis [15]. ES is a destructive osteolytic lesion that extends into the cortical, periosteum and soft tissues. This feature observed in $X$-rays is not pathognomonic and other lesions can have the same image pattern [9]. Some findings, such as the presence of a soft tissue mass and the patient's age may contribute to the formulation of ES diagnosis. The final diagnosis is confirmed after biopsy and histopathological analysis.

ES frequently grows rapidly and causes distant metastasis, particularly in the lung, bone marrow and bone [18]. In the present case, the patient had an ES in the mandible after the presence of the primary tumor in the femur. In new cases, $20 \%$ to $30 \%$ are metastatic $[19,20]$. Approximately $10 \%$ of reported cases occurring in the mandible are metastases [21]. The 5-year survival rate of patients with metastasis at diagnosis is approximately $20 \%$ [22]. In $30 \%$ to $40 \%$ of patients, recurrent tumors present either locally, distally or both [23]. Could this case represent an undetected bone metastasis during initial diagnosis? Therefore, an accurate assessment of patients with ES must be made to detect the extent of the primary tumor and a possible metastasis, to ensure an effective treatment. The association of the conventional imaging methods such as radiography, CT, MRI, combined with scintigraphy or Positron Emission Tomography/ Computed tomography PET /CT) that assess the metabolic activity of cancer cells, is essential for correct diagnosis of ES [24]. In the present case, MRI demonstrated the extension of the primary lesion and its relationship with the other anatomic structures such as the muscles. The coronal CT images of mandible showed destruction of the buccal and lingual cortical. In the window for soft tissue, an extra osseous mass was shown. $\mathrm{CT}$ was also used in the control of lesion after one year and showed a reduction in lesion. However, these methods only are limited for this evaluation. In this case, the association of other imaging methods such as scintigraphy or PET/CT should have been performed initially to detect metastasis and to evaluate the therapeutic response [24]. Scintigraphy detects metastasis indirectly by bone remodeling and PET/CT identifies lesions based on metabolic activity.

\section{CONCLUSION}

The use of different modalities of images in the diagnosis of ES is very important for evaluation, treatment 
and prognosis of this neoplasm.

\section{Collaborators}

All authors participated in the writing and revision of the manuscript. Marcelo Garcia made the

\section{REFERENCES}

1. Ewing J. Diffuse endothelioma of bone. CA Cancer J Clin. 1921;21:17-24. doi: 10.3322/canjclin.22.2.95.

2. Karski EE, Matthay KK, Neuhaus JM, Goldsby RE, Dubois SG. Characteristics and outcomes of patients with ewing sarcoma over 40 years of age at diagnosis. Cancer Epidemiol. 2013;31(1): 29-33. doi: 10.1016/j.canep.2012.08.006

3. Manor E, Kapelushnik J, Brennan PA, Bodner L. Chromossomal aberrations in primary Ewing Sarcoma of the mandible. $\mathrm{Br}$ J Oral Maxillofac Surg. 2012;50(6):574-6. doi: 10.1016/j. bjoms.2011.09.016

4. Le Deley MC, Delattre O, Schaefer KL, Burchill SA, Koehler G, Hogendoorn PC, et al. Impact of EWS-ETS fusion type on disease progression in Ewing's sarcoma/peripheral primitive neuroectodermal tumor: Prospective results from the cooperativeEuro-E.W.I.N.G. 99 trial. J Clin Oncol. 2010;28(1):1982-88. doi: 10.1200/JCO.2009.23.3585

5. de Alava E, Lessnick SL, Sorenson PH. Ewing sarcoma. In: Fletcher CDM, Bridge JA, Hogendoorn PCW, Mertens F, editors. $\mathrm{WHO}$ classification of tumours of soft tissue and bone. 4th ed. Lyon: International Agency for Research on Cancer; 2013. p. 306-9.

6. Moore DD, Haydon RC. Ewing's sarcoma of bone. Cancer Treat Res. 2014;162:93-115.

7. Shibasaki M, Iwai T, Maegawa J, Inayama Y, Yokosuka T, Yokota S, et al. Mandibular Ewing sarcoma with chromosomal translocation $t(21 ; 22)(q 22 ; q 12)$. J Craniofac Surg. 2013;24(4):1469-72. doi: 10.1097/SCS.0b013e31829030ed

8. Ralapanawa DM, Jayawickreme KP, Ekanayake EM, Kumarihamy KW. Spinal intradural metastasis from scapular Ewing Sarcoma. BMC Res Notes. 2015;8(1):298. doi: 10.1186/s13104-0151263-0

9. Bornstein MM, von Arx T, Altermatt HJ. Loss of pulp sensitivity and pain as the first symptoms of a Ewing's sarcoma in the right maxillary sinus and alveolar process: report of a case. J Endod. 2008;34(12):1549-53. doi: 10.1016/j.joen.2008.08.028

10. Wood RE, Nortje CJ, Hesseling P, Grotepass F. Ewing's tumor of the jaws. Oral Surg Oral Med Oral Pathol. 1990;69(1):120-7. doi: 10.1016/0030-4220(90)90280-6

11. Lopes SLPC, de Almeida SM, Costa ALF, Zanardi VA, Cendes F. Imaging findings of Ewing's sarcoma in the mandible. J Oral Sci. 2007;49(1):167-71. doi: 10.2334/josnusd.49.167

12. Bacchini P, Marchetti C, Mancini L, Present D, Bertoni F, Stea G. Ewing's sarcoma ofthe mandible and maxilla: a report of three acquisition and interpretation of the images of the femur region. Fabrício R. Amaral, Amaro I.V. Silva, Cláudia S. Valério, Claúdia A.A. Cardoso e Flávio R. Manzi evaluated the patient and made the acquisitions and interpretation of the images of the orofacial region.

cases from the Istituto Beretta. Oral Surg Oral Med Oral Pathol. 1986;61(1):278-83. doi: 10.1016/0030-4220(86)90375-0

13. Ko E, Brouns ER, Korones DN, Pochal WF, Philipone EM, Zegarelli DJ, et al. Primary Ewing sarcoma of the anterior mandible localized to the midline. Oral Surg Oral Med Oral Pathol Oral Radiol. 2013;115(6):46-50. doi: 10.1016/j.00oo.2012.11.010

14. Kutluk MT, Yalcin B, Akyuz C, Varan A, Ruacan S, Buyukamukcu M. Treatment results and prognodtic factors in Ewing sarcoma. Pediatr Hematol Oncol. 2004;21(1):597-610. Doi: 10.1080/08880010490501006

15. Hattori T, Yamakawa H, Nakayama N, Kuroda T, Andoh T, Sakai N, et al. Skull metastasis of Ewing's sarcoma: three case reports. Neurol Med Chir. 1999;39(1):946-49. doi: 10.2176/ nmc.39.946

16. Cotterill SJ, Ahrens S, Paulussen M, Jürgens HF, Voûte PA, Gadner $\mathrm{H}$, et al. Prognostic factors in Ewing's tumor of bone: analysis of 975 patients from the European intergroup cooperative Ewing's sarcoma study group. J Clin Oncol. 2000;18(1):3108-14. doi: 10.1200/JCO.2000.18.17.3108

17. Behnia H, Motamedi MHK, BruKsch KE. Radiolucent lesion of the mandibular angle and ramus J Oral Maxillofac Surg. 1998; 56(1):1086-90. doi: 10.1016/S0278-2391(98)90262-2

18. Lin PP, Wang Y, Lozano G. Mesenchymal Stem Cells and the Origin of Ewing's Sarcoma. Sarcoma. 2011;276463. doi: $10.1155 / 2011 / 276463$

19. Rodríguez-Galindo C, Navid F, Liu T, Billups CA, Rao BN, Krasin MJ. Prognostic factors for local and distant control in Ewing sarcoma family of tumors. Ann Oncol. 2008;19(4):814-20. doi: 10.1093/annonc/mdm521

20. Bernstein $M$, Kovar $H$, Paulussen $M$, Randall RL, Schuck $A$, Teot LA, et al. Ewing's sarcoma family of tumors: current management. Oncologist. 2006;11(1):503-19. doi: 10.1634/ theoncologist.11-5-503.

21. Lopes SL, Almeida SM, Costa AL, Zanardi VA, Cendes F. Imaging findings of Ewing's Sarcoma in the mandible. J Oral Sci. 2007;49(2):167-71. doi: 10.2334/josnusd.49.167

22. Tsokos M, Alaggio RD, Dehner LP, Dickman PS. Ewing sarcoma/ peripheral primitive neuroectodermal tumor and related tumors. Pediatr Dev Pathol. 2012;15:108-26. doi: 10.2350/1108-1078-PB. 1

23. Jürgens $H$, Exner $U$, Gadner $H$, Harms D, Michaelis J, Sauer $R$, et al. Multidisciplinary treatment of primary Ewing's sarcoma of bone. A 6-year experience of a European Cooperative Trial. Cancer. 1988;61(1):2332. doi: 10.1002/1097-0142(19880101)61:1<23::AIDCNCR2820610106>3.0.CO;2-M 
24. Guimarães JB, Rigo L, Lewin F, Emerick A. The importance of $\mathrm{PET} / \mathrm{CT}$ in the evaluation of patients with Ewing tumors. Radiol Bras. 2015;48(3):175-80. doi: 10.1590/0100-3984.2013.1887
Received on: 11/9/2017

Final version resubmitted on: 21/11/2017 Approved on: 1/12/2017 